\title{
Measurement of Destination Personality: An Updated Literature Review
}

Urooj Zulfiqar, Harcharanjit Singh, Asfandyar Khan, Ikram-Ullah, Aliya Yesmin, Zainab Mohammed Alwan Al-Juboori

To Link this Article: http://dx.doi.org/10.6007/IJARBSS/v12-i1/12231

DOI:10.6007/IJARBSS/v12-i1/12231

Received: 16 November 2021, Revised: 21 December 2021, Accepted: 06 January 2022

Published Online: 23 January 2022

In-Text Citation: (Zulfiqar et al., 2022)

To Cite this Article: Zulfiqar, U., Singh, H., Khan, A., Ikram-Ullah, Yesmin, A., \& Al-Juboori, Z. M. A. (2022). Measurement of Destination Personality: An Updated Literature Review. International Journal of Academic Research in Business and Social Sciences, 12(1), 2631-2656.

Copyright: (c) 2022 The Author(s)

Published by Human Resource Management Academic Research Society (www.hrmars.com)

This article is published under the Creative Commons Attribution (CC BY 4.0) license. Anyone may reproduce, distribute, translate and create derivative works of this article (for both commercial and non0-commercial purposes), subject to full attribution to the original publication and authors. The full terms of this license may be seen at: http://creativecommons.org/licences/by/4.0/legalcode

Vol. 12, No. 1, 2022, Pg. $2631-2656$

Full Terms \& Conditions of access and use can be found at http://hrmars.com/index.php/pages/detail/publication-ethics 


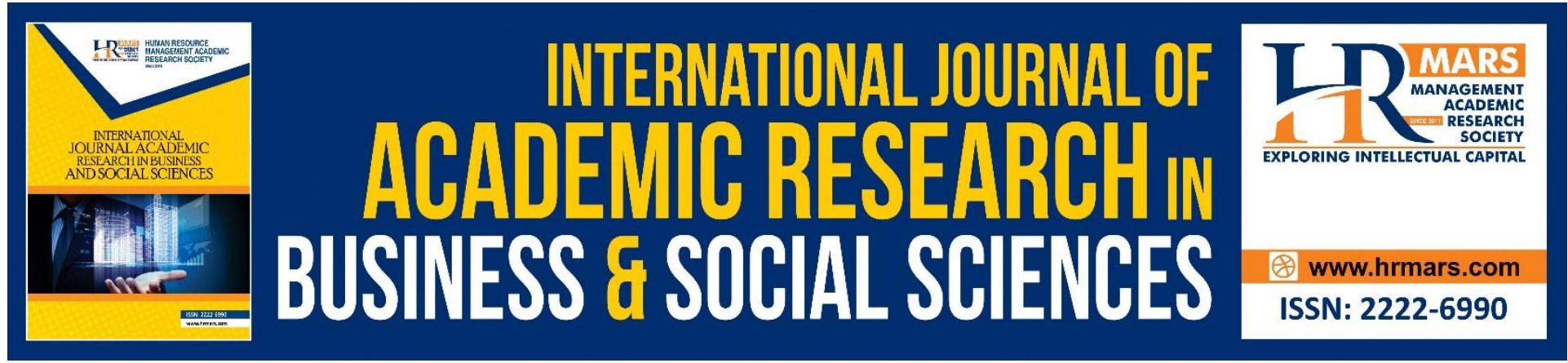

\title{
Measurement of Destination Personality: An Updated Literature Review
}

\author{
Urooj Zulfiqar
}

PhD. Scholar International business school Universiti Teknologi Malaysia, Johar Bahru Corresponding Author Email: zurooj@graduate.utm.my

\author{
Dr. Harcharanjit Singh \\ Asso. Prof. Singh Universiti Teknologi Malaysia, Kuala Lumpur \\ Email: harcharanjit@utm.my
}

\begin{abstract}
Asfandyar Khan
PhD. Scholar International business school Universiti Teknologi Malaysia, Johar Bahru Email: kasfandyar@graduate.utm.my
\end{abstract}

\section{Ikram-Ullah}

PhD. Scholar International business school Universiti Teknologi Malaysia, Kuala Lumpur Email: ikramullah2317@gmail.com

\section{Aliya Yesmin}

PhD. Scholar International business school Universiti Teknologi Malaysia, Kuala Lumpur Email: yaliya@graduate.utm.my

\section{Zainab Mohammed Alwan Al-Juboori}

PhD. Scholar International business school Universiti Teknologi Malaysia, Kuala Lumpur Email: maazainab2@graduate.utm.my

\begin{abstract}
Destination branding has been an extensively investigated idea as governments and corporations seek to reposition their respective destinations' images in the mainstream sphere. Many areas of destination branding are researched; not only for the purpose of branding or rebranding locations, but also to stimulate local economies. The purpose of this study is to obtain information about destination personality from the literature accessible in research sources. Based on the citation indices and downloads from digital sites and libraries, this research picked 28 noteworthy papers on the issue that were published in the recent 12 years, and then conducted the analysis on them. This review paper presents the findings of previous researches and the approaches used therein. The findings reveals that 42 -item BPS
\end{abstract}


of (Aaker, 1997) were used to measure destination personality. However, the most noticeable dimensions of destination personality based on which human characteristics are attributed to the destination are sincerity, excitement and conviviality and researchers used these dimensions are most commonly to measure destination personality. These noticeable dimensions of destination personality sincerity and excitement were found to be two main dimensions and conviviality is newly specific to destination. Researchers, marketers, and government officials might benefit from an increased understanding of notions of destination personality and its implications in tourism, which could lead to adjustments and improvements in the branding of tourist, business, and other kinds of destinations. Hence, it is essential to emphasise that this paper is only a qualitative evaluation of the literature and therefore confined to the results of prior research in this area.

Keywords: Big-five Factor Model, Destination Personality, Literature Review

\section{Introduction}

Destination personality consider as brand personality in context of tourism literature. Though, the study of product/brand personality research had begun in the early 1960s in the domain of consumer goods (Ekinci \& Hosany, 2006). Conceivably, the identification and application of destination personality concept is quite new in tourism field (Ekinci et al., 2007; Ekinci \& Hosany, 2006; Gnoth et al., 2007; Pitt et al., 2007; Tasci \& Kozak, 2006). Destination personality contributes to encouraging tourists and in the marketing of destinations (Baloglu et al., 2014; Ekinci \& Hosany, 2006; Usakli \& Baloglu, 2011). According to Chen and Phou (2013) destination personality has been widely used by marketers to competitively position their cities in the tourism market. This study aims to contextualise prior research results in terms of destination personality.

The aim of this study is to provide an overview of destination personality studies from 20062018. Table 2 showed the updated literature review on destination personality presented in earlier studies, as well as the research gaps for future research. The purpose of this study is to create a better knowledge of the destination personality on the basis of the most recent findings, as well as to identify methodological concerns and the value of new information for future research in the destination.

Particularly, this paper offers a review and debate of the literature, concept, measurement and dimensions of destination personality. Additionally, the methodological methods for establishing destination personality are examined in an attempt to assist researchers in recording and determining the evolution of destination personality through years.

The scope of the most recent review was limited to the following issues:

- What are the latest findings of destination personality research?

- What are the dimensions of the personality image?

- How to measure destination personality in tourism related studies?

\section{Conceptualization of Personality}

The word personality said to be derived from the Latin word "persona" which used in contras of "mask" meaning. "Persona" reflects the characteristics of an individual in any specific role rather than the original person behind the mask. Over time, this concept comprehends with person attitude and behavioural characteristics (Aslan, 2008). Similarly, it is very common to listen about people is that person has a good or bad personality. The actions are the reflection of the personality and it also defines it. Different behaviour distinguishes the 
uniqueness of every personality. Personality of an individual is the composition of mental characteristics; thought patterns and sentiments all this stimulates one to behave in a certain way. Personality is "The characteristics or blend of characteristics that make a person unique."

Basically, temperaments or emotional tone also expressed the Personality. It is commonly Stemmler and Wacker (2010) said in personality psychology field that "Some things change; Some things stay the same. suggested that "personality is a dynamic organization, inside the person, of psychophysical systems that create the person's characteristic patterns of thoughts, feelings and behaviours."

In accordance with Mischel and Shoda (1995) demonstrated that personality gives the directions and coherence to an individual's life with the dynamic organization of cognitions, affects and behaviours. Nature (genes) and nature experiences contains both personality structures and processes. Likewise, an individual personality also depicts its values, beliefs, and expectations (Washington et al., 2006). Correspondingly, Personality development contains many potential factors. Following this an individual's personality acquire values, beliefs and expectations from surrounding environment, socialization and with unique experiences which also enhance the self-concept/self-esteem/self-regulation/selfefficacy/self-awarness and self-knowledge in personality (Ward, 1974). The distinctive pattern of behaviours, continuities, permanence of personality traits and dispositions over time defines personality development (Denissen \& Penke, 2008).

\section{Types of personality}

The individual behavioural differences personality traits such as Introversion/Extroversion $(\mathrm{I} / \mathrm{E})$ are always comprehensively explained by personality theorists in terms to used and understand them accordingly. Previous studies indicate that there is always a high emphasize on introversion-extroversion as the main traits of big-five personality model.

As well as Burruss and Kaenzig (1999) cited that Jung (1923) was the pioneer for the exploration of personality and development of its construct's extroversion and introversion. Jung observed the human behaviour and habits as patterns and worked to recognize and rationalize these differences of personality according to uniqueness of human behaviour variable patterns. In early twentieth century, the concept of these two personality traits introvert/extravert were already existed, Eysenck (1992) research had confirmed that introvert/extravert factors were very important dimensions of personality. Each dimension has its own characteristics, such as sociality, activity, expansiveness, etc.

\section{Extroversion}

Extroversion is "attitude-type characterized by concentration of interest on the external object". Extroverts found to be more "social-oriented", "expressive", "articulate", "fun loving", "easily caught the attention of other people", much comfortable in group settings. Due to the fact that every individual differs from others in emotional reaction, this is referred to as "personality differences". Past studies stated extroverts generates more positive experience in comparison to introverts, so extroversion encounter positive affect (Larsen \& Ketelaar, 1991). It also signifies extroversion to high active (arousal), assertiveness, impulsiveness, social behaviour and practicing positive emotions are its tendency (Jalili \& Mall-Amiri, 2015). Extroverts have the ability to deal with life events by using problem-solving skills that provide them with a positive sense of self-worth (Freyd, 1924; Jalili \& Mall-Amiri, 2015; Muharrami et al., 2013). However, at the other end of the spectrum from structural 
work in personality, extroversion interpersonal nature is not a monolithic characteristic, but rather is composed of two separate higher order qualities, namely, Affiliation and Agency. Affiliation is more about amusement, social interactions, being warm hearted, affable and loving. Agency reflects self-efficacy in terms of fulfilling goals in subjective sense, leadership roles, assertiveness and social power of control (Busato et al., 2000).

Additionally, Hogan (1983) expressed that extroversion is characterised by traits such as openness to new experiences, a desire to help others, and a capacity for self-advocacy. Extroversion is divided into two subgroups: Sociability and Ambition. In accordance to this some extroverts can be more sociable and like other group's company and some extroverts can be self-confident, dominant and leaders. Furthermore, extroverts are highly competitive and focused regarding reward achievements (Hills \& Argyle, 2001).

\section{Introversion}

Morrone-Strupinsky and Lane (2007) defined introverts as self-oriented, self-responsible, persistent and intrinsically motivated towards their acts and results. According to studies, Introversion does not prefer vast social life they are more intended towards rich inner life. Introverts are quiet, simple, prefer focused and closed relationship with small no of people (Niranga \& Dharmadasa, 2018). They are very anxious in nature but good in thinking while they are tranquil and follow internal directions preferably.

In invasion situation they isolate their self as they couldn't manage to be themselves and strive to be extroverted, spontaneous or crazy. They are very inside-in regarding their best things, and not actively participate or reluctant in a group situation just because they need time to fully develop their ideas and they think before speak. They have the skill to be appeared as extroverts when needed. Seemingly they appeared as anti-social or shy but they are social but in a different way. They have a good capacity to listen, planning, focusing, oneon-one interactions and can perform independently (Dannar, 2016). Interestingly they like to express themselves by writing, have ability to hold their self-back in any situation, be calm and get perspective. Thus, introverts are cooperative and facilitating in relationships. Introvert \& extrovert personality traits chart shown in Figure 1. 
Figure 1: Introvert \& Extrovert Personality Traits Chart

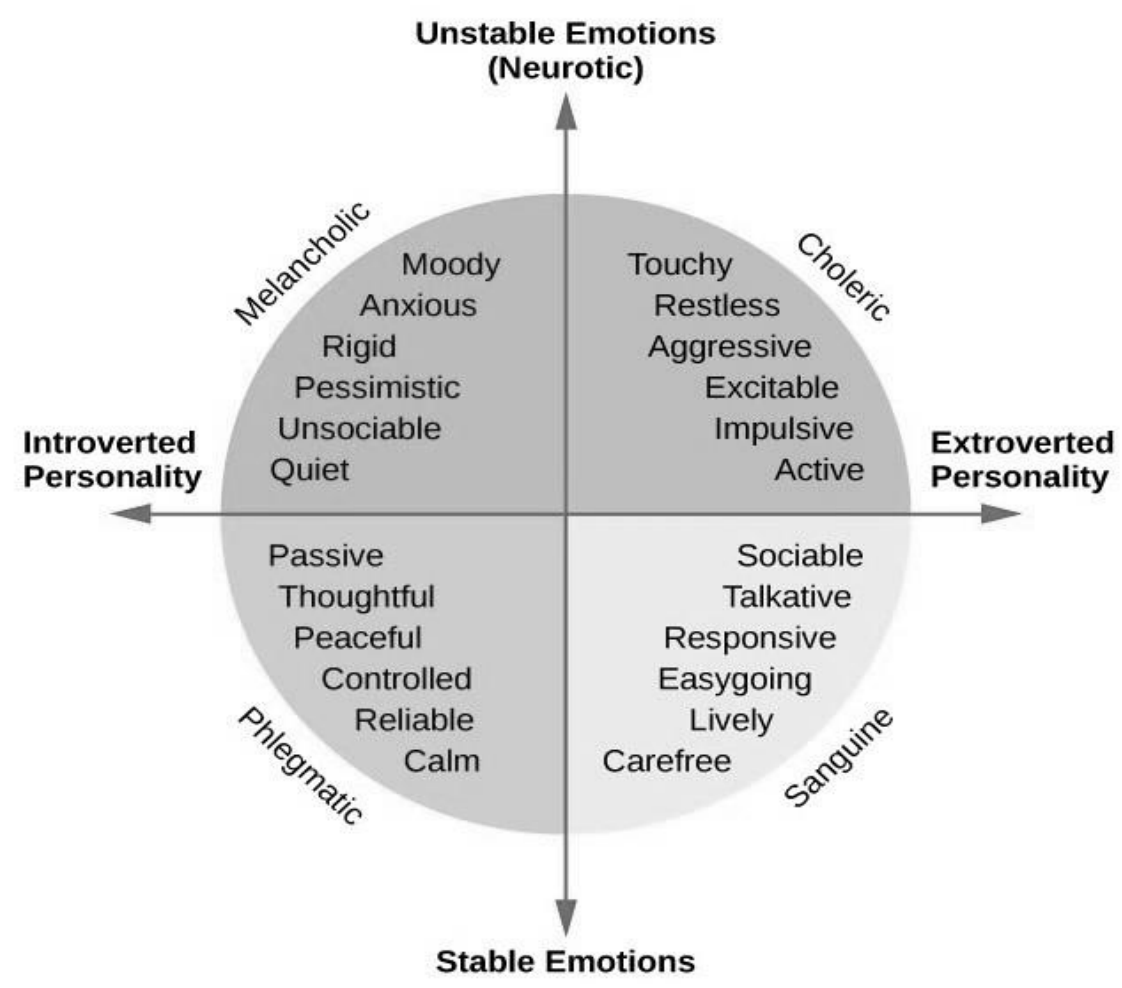

Source: Eysenck (1985)

\section{Big-five Personality Traits}

Initially the 16-item inventory of personality traits were developed by Raymond Cattel in 1964 with Sixteen personality factor questionnaire (16PF) items to analyse these traits. Costa Jr and McCrae (1992) later established the FFM (Five Factor Model), which precisely describes the personality to measure in terms of five broad factors.

Among all the developed models for personality like Allport's trait theory, Cattell's 16FM, Eysenck's Big Three, and the Myers-Briggs Type Indicator (MBTI), Costa Jr and McCrae (1992) model the Big Five Model (Five Factor Model) is commonly used for personality traits measurement in management and marketing literature.

This Five Factor Model is being created after eliminating plenty of adjective to make it more precise with characterization of Five dimensions. However, from the several years this model has been used by many researchers, has constantly used even today attracting attention and trust of the academicians due to its appropriate characteristics. This model involves the five main dimensions of personality that explain an individual.

In addition to the preceding research, the Big Five Personality Traits - a composite of five different categories-are also explained in Figure 2 that are Extraversion, Neuroticism, Openness, Conscientiousness, and Agreeableness (Barrick \& Mount, 1991; Landers \& Lounsbury, 2006; Rothmann \& Coetzer, 2003; Stajkovic et al., 2018). 
Figure 2: Five Personality Model,

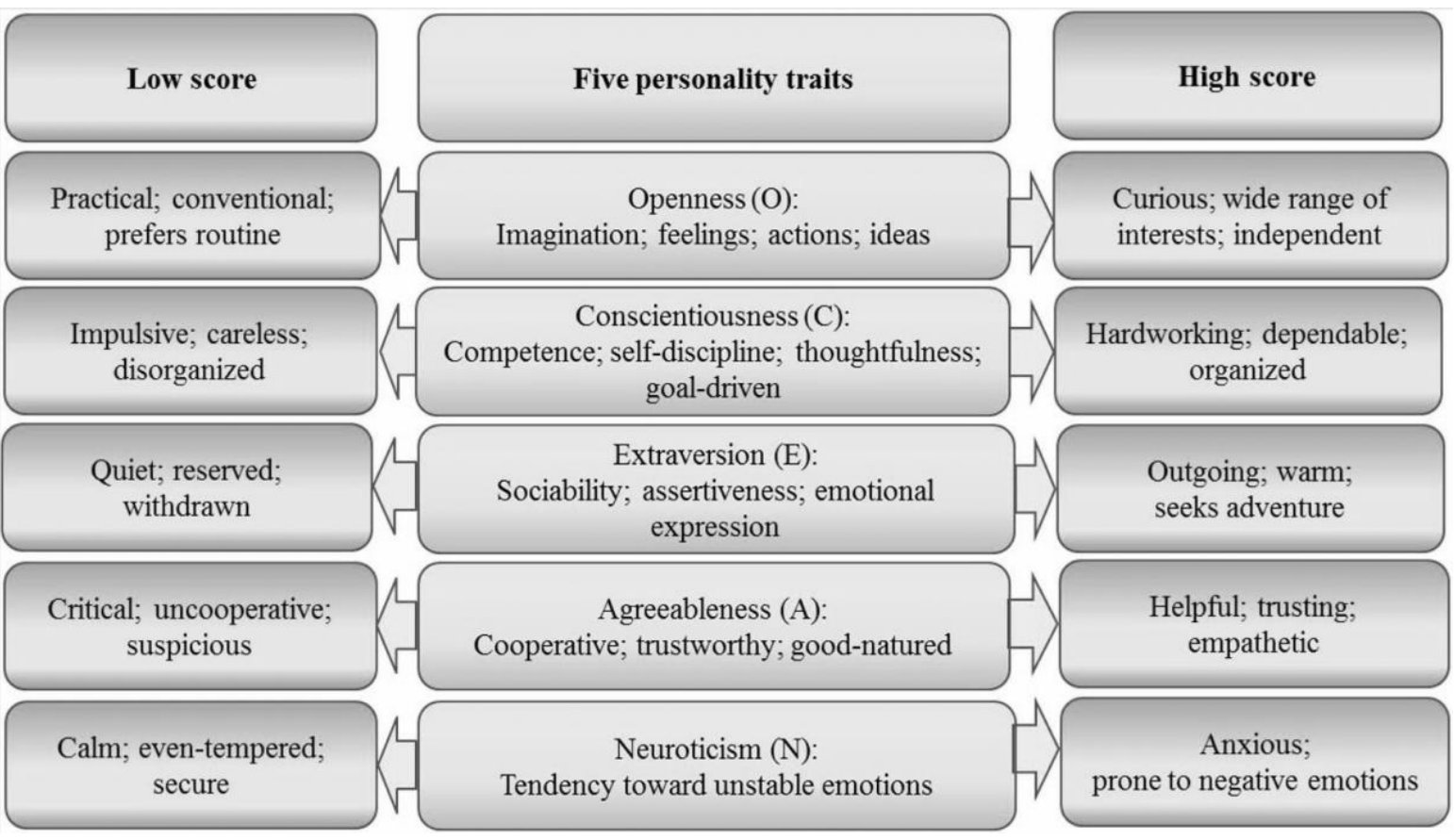

Source: Goldberg (1990)

\section{Extraversion}

Individuals with an extravagant personality include being talkative, gregarious, socially poised, assertive, leading, outgoing, energetic and cheerful (Barrick \& Mount, 1991). The individual with high level of extraversion has obtained stable and positive affect and behaviours. They are very positive regarding future, less vulnerable and very open towards competition (Eysenck, 1981), not like low level of extraversion who prefer to be alone, less participated in activity, calm and staying at the back with avoidance of stimulation (Lucas \& Diener, 2001).

\section{Neuroticism}

Individuals with features of Calm, relaxed, satisfied with self, clear cut personality, stresstolerant, pride self on objectivity are highly emotionally stable personality. Traits opposite of this emotional stability behaviour involve negativity for their-self, being worried, anxious, insecure, shy, tense, depressed, and always worry about other opinions present neurotic personality traits (McCrae \& Costa, 1987). Individual with low level of emotional stability always tends to unsuccessful to have healthy interactions with people around them (Clark \& Watson, 1991).

\section{Openness}

Traits used to describe openness to experience personality type include creative, intellectual, analytic, imaginative, open to other people's perspective, adventurous, narrow and have a broad level of intellectual curiosity at the end of continuum. Openness personality always value intellectual stimulus. Comparatively, lees open to experience personalities are associated with conservative, simplicity, indifferent, behaviourally rigid and conformist in their cognition (Dollinger \& Orf, 1991; McCrae, 1993). 


\section{Conscientiousness}

This personality trait commonly categorized as careful, responsible, systematic, selfdisciplined, determined, detailed, highly success ambitious. High conscientiousness personality is eager to achieve their goals. In contrast with this individual who are irresponsible, unplanned, disorganized, poor decision making, easily distracted have lower conscientiousness dimension level (Dollinger \& Orf, 1991; McCrae \& Costa, 1987).

\section{Agreeableness}

Personality involved in this dimension are eager, collaborative, behaves in a given way, sympathetic, warm, straightforward and compassionate. They avoid conflicts and have cooperative manners. Critical, skeptical, behave condescend, hard headed, express hostility directly, tries to push limits and aggressive to others have lesser agreeableness level. When it comes to assessing the quality of one's interpersonal attitude, agreeableness is a personality attribute (e.g. disbelieving vs. believing) (Costa Jr et al., 1991; Graziano \& Eisenberg, 1997).

\section{Tourism and Personality}

Tourism is highly based on tourist experiences as tourist respond back towards the destinations on the basis of their personality traits. Gretzel et al. (2006) illustrated how tourist personality characteristics may be utilised to promote tourist activities and, consequently, destinations. Furthermore, it has also been demonstrated that tourist roles are supported by tourist personality traits.

Within the tourism and hospitality studies, the Big Five model is also regarded to be the most prominent (Leung \& Law, 2010; Ying \& Norman, 2017). Empirical studies have been conducted concerning the following: travel decision-making (Tsiakali, 2018), tourism information research (Kavenská \& Simonová, 2015; Kuo et al., 2016) and tourism destination branding (Kumar \& Nayak, 2018; Li \& Kaplanidou, 2013).

Therefore, it is essential to understand the relationship between personality traits and visitor feelings in the tourism industry (Berno \& Ward, 2005). The Big Five model explains significant differences in consumption of emotions (Jani \& Han, 2013; Lin et al., 2014), and visitor attitudes (Lee \& Tseng, 2015; Moghavvemi et al., 2017).

According to Jani and Han (2013), extraversion influences positive emotions, agreeableness influences both positive and negative emotions, and neuroticism influences negative emotions. Furthermore, it has been stated that the Big Five personality traits play a vital role in predicting tourists' behaviours regarding future intentions (Servidio, 2015) within various contexts, including hotels (Bellou et al., 2018; Huang et al., 2014; Jani \& Han, 2014; Tang \& Lam, 2017) restaurants (Kim et al., 2010), expeditions (Kim et al., 2018), eco-tourism (Kvasova, 2015; Yoo \& Gretzel, 2011) and adventure travel (Servidio, 2015; Vespestad \& Mehmetoglu, 2017). However, in the field of tourism, in spite of the importance of visitors' personalities, research concerning the role of tourists' personalities in their emotional stimulation (Larsen, 2018) (Servidio, 2015) and behaviour (Faullant et al., 2011; Jani \& Han, 2014a, 2014b) is scarce. Leri and Theodoridis (2020) provide a insight that how attracting visitors effects with high or average personality dimensions of openness to experience, extraversion, agreeableness and conscientiousness, or with low neuroticism. Moreover, past study have 
indicated that human personality is a major factor affecting marketing communication (Leung \& Law, 2010).

\section{Destination Personality}

However, for many decades, tourism research has mostly focused on the destination image, academics have paid less attention to destination personality due to the concept's relative novelty in the tourist sector. Distinguishing and substituting destinations based on their functional features reduces their uniqueness and makes them less identifiable. Thus, including extra characteristics for destination personality such as value propositions may aid in distinguishing destinations and attracting travellers. When marketing their branded cities and destinations in a highly competitive tourist sector, destination marketers employ destination personality to distinguish and position their brands. Indeed, destination personality is increasingly being used as a metaphor for marketing and positioning in the tourism industry. Many researchers defined destination personality in different way as shown in Table 1.

Table 1: Destination Personality Definitions

\begin{tabular}{ll}
\hline Author/s & Definitions \\
\hline Keller (1993) & "The symbolic function of a brand whereas brand image \\
& $\begin{array}{l}\text { refers to both symbolic and functional benefits of a brand" } \\
\text { "The set of human characteristics associated with a brand" } \\
\text { "Taker (1997) }\end{array}$ \\
Ekinci and Hosany (2006) & $\begin{array}{l}\text { Thes set human characteristics associated with a } \\
\text { This definition has been framed based on brand } \\
\text { personality model. }\end{array}$ \\
\hline
\end{tabular}

Based on the study of personality traits, the Big Five model (BFF) is very known. Its five measures are Openness to experience (curious, adventurous), extraversion (emotional, submissive) conscientiousness (self-indulgent, productive), agreeableness (skeptical, critical), and neuroticism (thin-skinned, anxious, irritable). With reference to human personality model, Aaker (1997) developed the Brand Personality Scale (BPS) for the analyzation of product/brand personality attributes (see Figure 3). Since then, this Aaker (1997) scale has been widely used to examining the product/brand personality. Aaker (1997) defines brand personality as "the set of human characteristics associated with a brand".

Following this, it can view that consumer perceives the brands as similar to humanlike traits, which is valuable sense to respond a brand emotionally that stimulate their opinions, purchase intension and consumer decision making. Consequently, Consumer feel more intended and supportive towards a brand regarding which they feel personally more relevant and this build positive relationship and leads in customer's trust towards the brand and increases his/her loyalty.

Aaker (1997) defined brand personality is the combination of characteristics which are similar to human but associated with product/brand cited in (Ekinci \& Hosany, 2006). Youthful, sporty, energetic, outdoorsy or sophisticated can be traits characteristics. This is why, brands are often explained by intangible characteristics. For instance, humanistic characteristic is utilized to describe some brands and products such as "masculine" for Malborow (Ekinci \& Hosany, 2006), "Cool" for Coca-Cola and "Young" for Pepsi (Aaker, 1997), 
"sophistication" for BMW (Phau \& Lau, 2000), "unique" in the case of Dr. Pepper, "intelligent" to describe IBM computers, and "feminine" to describe Channel perfumes (Hassan, 2001). Since Aaker (1997) describes five dimensions and fifteen aspects that characterise a brand's personality as traits that are exclusive to humans and are thus attributable to a brand, as seen in Figure 3.This five-factor scale (BPS) includes dimension of "Excitement (which means the characters of full-spirit, trendy, courage, and high imagination, as well as up-to-date in making difference and innovation)"; "Sincerity (which means the characters of honest, humble, down- to-earth, family-oriented, small- town, friendly, sincere, real, original, and simple)"; "Ruggedness (which is the brand characteristic that is associated with the ability, that is the brand characteristic in supporting outdoor activities and the strength or durability of product)" "Competence (which means security, intelligence, tenacity, skill convenience, ability to be reliable and trusted by consumers) and Sophistication (which means characters related to exclusivity that is formed by excellence of prestige, brand image, and attraction offered to customers)".

Figure : 3 Brand Personality Model

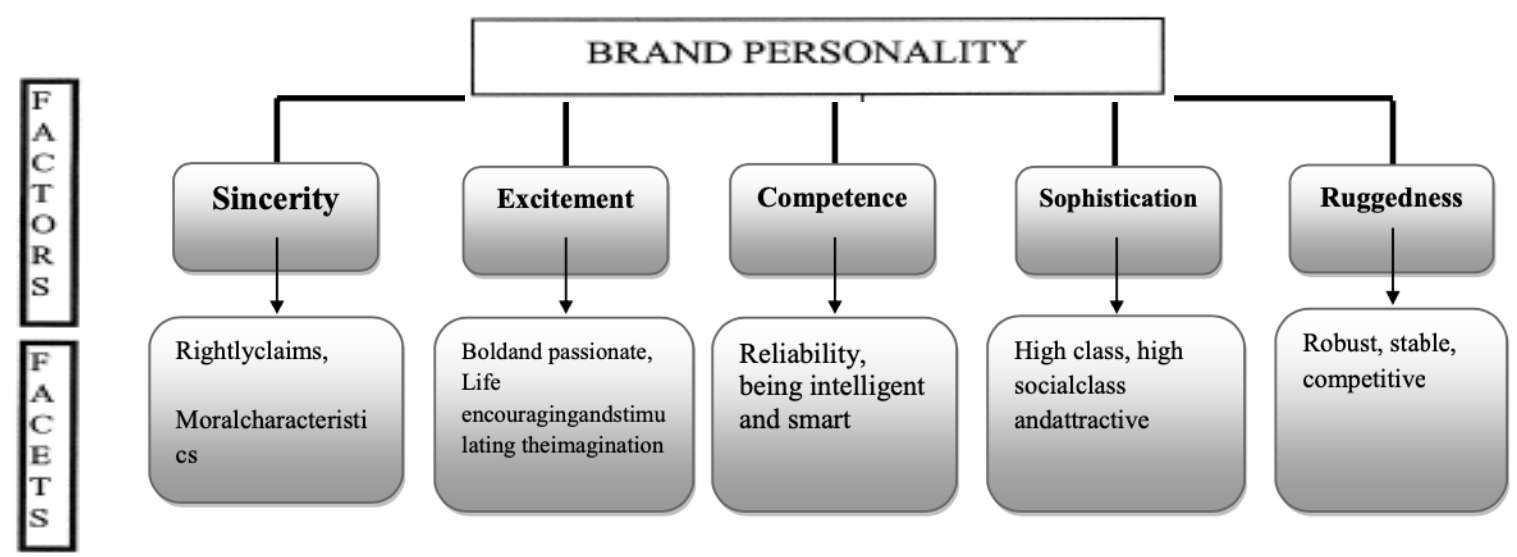

Source : Aaker (1997)

\section{Method}

In order to accomplish the purpose, based on the citation indices and downloads from digital sites and libraries, this research picked 28 noteworthy papers on the issue that were published in the recent 12 years, and then conducted the analysis on them (see Table 2). The academic community generally acknowledges that there is no, definitive and solitary system that emerges as a one-size-fits-all answer for grading papers (McKercher et al., 2006). The journal in which papers were published are shown in Table 2. 
Table 2: Destination personality studies citation record from 2006-2018

\begin{tabular}{|c|c|c|c|}
\hline Author (s) & Title & Journal & $\begin{array}{l}\text { Google } \\
\text { Citations }\end{array}$ \\
\hline $\begin{array}{l}\text { Ekinci \& } \quad \text { \& } \\
\text { Hosany } \\
(2006)\end{array}$ & $\begin{array}{l}\text { "Destination personality: An } \\
\text { application of brand } \\
\text { personality to tourism } \\
\text { destinations" }\end{array}$ & "Journal of Travel Research" & 1134 \\
\hline $\begin{array}{l}\text { Hosany et al } \\
(2006)\end{array}$ & $\begin{array}{l}\text { "Destination image and } \\
\text { destination personality: An } \\
\text { application of branding } \\
\text { theories to tourism places" }\end{array}$ & $\begin{array}{l}\text { "Journal of Business } \\
\text { Research" }\end{array}$ & 1241 \\
\hline $\begin{array}{l}\text { Murphy et al } \\
\text { (2007b) }\end{array}$ & $\begin{array}{lr}\text { "Destination } & \text { brand } \\
\text { personality: } & \text { Visitor } \\
\text { perceptions of a regional } \\
\text { tourism destination" }\end{array}$ & "Tourism Analysis" & 165 \\
\hline $\begin{array}{l}\text { d'Astous and } \\
\text { Boujbel } \\
(2007)\end{array}$ & $\begin{array}{l}\text { "Positioning countries on } \\
\text { personality dimensions: Scale } \\
\text { development } r \text { and } \\
\text { implications for country } \\
\text { marketing" }\end{array}$ & $\begin{array}{l}\text { "Journal of Business } \\
\text { Research" }\end{array}$ & 329 \\
\hline $\begin{array}{l}\text { Prayag } \\
(2007)\end{array}$ & $\begin{array}{l}\text { "Exploring the relationship } \\
\text { between destination image } \\
\text { and brand personality of a } \\
\text { tourist destination: an } \\
\text { application of projective } \\
\text { techniques" }\end{array}$ & $\begin{array}{l}\text { "Journal of Travel and } \\
\text { Tourism Research" }\end{array}$ & 132 \\
\hline $\begin{array}{l}\text { Pitt et al. } \\
(2007)\end{array}$ & 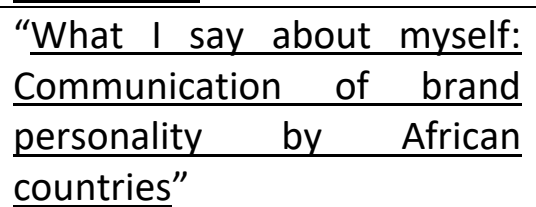 & "Tourism Management" & 229 \\
\hline $\begin{array}{l}\text { Murphy et al } \\
(2007 a)\end{array}$ & $\begin{array}{l}\text { "Using brand personality to } \\
\text { differentiate regional tourism } \\
\text { destinations" }\end{array}$ & "Journal of Travel Research" & 542 \\
\hline $\begin{array}{l}\text { Hosany et al } \\
(2007)\end{array}$ & $\begin{array}{l}\overline{\text { "Destination }} \\
\text { image and destination } \\
\text { personality" }\end{array}$ & $\begin{array}{l}\text { "International Journal of } \\
\text { Culture, Tourism and } \\
\text { Hospitality Research" }\end{array}$ & 459 \\
\hline $\begin{array}{l}\text { Ekinci et al } \\
(2007)\end{array}$ & $\begin{array}{l}\text { "Host image and destination } \\
\text { personality" }\end{array}$ & "Tourism Analysis" & 210 \\
\hline Sahin (2008) & $\begin{array}{l}\text { "Brand personality and } \\
\text { destination image of Istanbul: } \\
\text { A comparison across } \\
\text { nationalities" }\end{array}$ & Ddigitalscholarship.unlv.edu" & 29 \\
\hline $\begin{array}{l}\text { Lee et al } \\
(2010)\end{array}$ & $\begin{array}{l}\text { "Destination } \\
\text { personality: Cross-country } \\
\text { comparisons" }\end{array}$ & $\begin{array}{l}\text { "Proceedings of Australian } \\
\text { and New Zealand Marketing } \\
\text { Academy conference" }\end{array}$ & 16 \\
\hline $\begin{array}{l}\text { Stokburger- } \\
\text { Sauer (2011) }\end{array}$ & $\begin{array}{l}\text { "The relevance of visitors' } \\
\text { nation brand embeddedness }\end{array}$ & "Tourism Management" & 152 \\
\hline
\end{tabular}




\begin{tabular}{|c|c|c|c|}
\hline & $\begin{array}{l}\text { and personality congruence } \\
\text { for nation brand } \\
\text { identification, visit intentions } \\
\text { and advocacy" }\end{array}$ & & \\
\hline $\begin{array}{l}\text { Usakli and } \\
\text { Baloglu } \\
(2011)\end{array}$ & $\begin{array}{l}\text { "Brand personality of tourist } \\
\text { destinations: An application } \\
\text { of self-congruity theory" }\end{array}$ & "Tourism Management" & 746 \\
\hline $\begin{array}{l}\text { Killic \& Sop } \\
(2012)\end{array}$ & $\begin{array}{l}\text { "Destination } \\
\text { personality, self- } \\
\text { congruity and loyalty" }\end{array}$ & $\begin{array}{l}\text { "Hospitality Management } \\
\text { and Tourism" }\end{array}$ & 85 \\
\hline $\begin{array}{l}\text { Chen and } \\
\text { Phou (2013) }\end{array}$ & $\begin{array}{l}\text { "A closer look at destination: } \\
\text { Image personality, } \\
\text { relationship and loyalty" }\end{array}$ & "Tourism Management" & 718 \\
\hline $\operatorname{Lin}(2013)$ & $\begin{array}{l}\text { "Determinants of revisit } \\
\text { intention to a hot springs' } \\
\text { destination: Evidence from } \\
\text { Taiwan" }\end{array}$ & $\begin{array}{l}\text { "Asia Pacific Journal of } \\
\text { Tourism }\end{array}$ & 46 \\
\hline $\begin{array}{l}\text { Kim and } \\
\text { Lehto (2013) }\end{array}$ & $\begin{array}{l}\text { "Projected and } \begin{array}{r}\text { perceived } \\
\text { destination }\end{array} \\
\text { personalities: The case of } \\
\text { South Korea" }\end{array}$ & "Journal of travel research" & 182 \\
\hline $\begin{array}{l}\text { Xie and Lee } \\
(2013)\end{array}$ & $\begin{array}{l}\text { "Toward the perspective of } \\
\text { cognitive destination image } \\
\text { and destination personality: } \\
\text { The case of Beijing" }\end{array}$ & $\begin{array}{l}\text { "Journal of Travel \& Tourism } \\
\text { Marketing" }\end{array}$ & 130 \\
\hline $\begin{array}{l}\text { Baloglu et al } \\
(2014)\end{array}$ & $\begin{array}{l}\text { "Destination image and } \\
\text { brand personality of Jamaica: } \\
\text { A model of tourist behaviour" }\end{array}$ & $\begin{array}{l}\text { "Journal of Travel \& Tourism } \\
\text { Marketing" }\end{array}$ & 138 \\
\hline $\begin{array}{l}\text { Kumar and } \\
\text { Nayak } \\
(2018)\end{array}$ & $\begin{array}{l}\text { "Destination personality: } \\
\text { Scale development and } \\
\text { validation" }\end{array}$ & $\begin{array}{l}\text { "Journal of Hospitality \& } \\
\text { Tourism Research" }\end{array}$ & 65 \\
\hline $\begin{array}{l}\text { Kim and Lee } \\
\text { (2015) }\end{array}$ & $\begin{array}{l}\text { "Impacts of city personality } \\
\text { and image on revisit } \\
\text { intention" }\end{array}$ & $\begin{array}{l}\text { "International Journal of } \\
\text { Tourism Cities" }\end{array}$ & 70 \\
\hline $\begin{array}{l}\text { Hultman et } \\
\text { al (2015) }\end{array}$ & $\begin{array}{l}\text { "Achieving tourist loyalty } \\
\text { through destination } \\
\text { personality, satisfaction, and } \\
\text { identification" }\end{array}$ & $\begin{array}{l}\text { "Journal of Business } \\
\text { Research" }\end{array}$ & 213 \\
\hline $\begin{array}{l}\text { Zeugner- } \\
\text { Roth and } \\
\text { Žabkar } \\
(2015)\end{array}$ & $\begin{array}{l}\text { "Bridging the gap between } \\
\text { country and destination } \\
\text { image: Assessing common } \\
\text { facets and their predictive } \\
\text { validity" }\end{array}$ & $\begin{array}{lll}\text { "Journal of Business } \\
\text { Research" }\end{array}$ & 120 \\
\hline $\begin{array}{l}\text { Aguilar et al } \\
\text { (2016) }\end{array}$ & $\begin{array}{l}\text { "Destination brand } \\
\text { personality: An application to } \\
\text { Spanish tourism" }\end{array}$ & $\begin{array}{l}\text { "International Journal of } \\
\text { Tourism Research" }\end{array}$ & 67 \\
\hline
\end{tabular}




\begin{tabular}{|c|c|c|c|}
\hline $\begin{array}{l}\text { Souiden et al } \\
\text { (2017) }\end{array}$ & $\begin{array}{l}\text { "Destination personality and } \\
\text { destination image" }\end{array}$ & $\begin{array}{l}\text { "Journal of Hospitality and } \\
\text { Tourism Management" }\end{array}$ & 162 \\
\hline $\begin{array}{l}\text { Pan et al } \\
(2017)\end{array}$ & $\begin{array}{l}\text { "Development and validation } \\
\text { of a destination personality } \\
\text { scale for mainland Chinese } \\
\text { travellers" }\end{array}$ & "Tourism Management" & 82 \\
\hline $\operatorname{Kim}_{(2018)}$ et al & $\begin{array}{l}\text { "Destination personality, } \\
\text { destination image, and intent } \\
\text { to recommend: The role of } \\
\text { gender, age, } \quad \text { cultural } \\
\text { background, and r prior } \\
\text { experiences" }\end{array}$ & "Sustainability" & 36 \\
\hline $\begin{array}{l}\text { Chi et al } \\
(2018)\end{array}$ & $\begin{array}{l}\text { "Examining } \\
\text { personality: Its antecedents } \\
\text { and outcomes" }\end{array}$ & $\begin{array}{l}\text { "Journal of Destination } \\
\text { Marketing \& Management" }\end{array}$ & 35 \\
\hline
\end{tabular}

\section{Findings and Discussion}

(Aaker, 1997) BPS is based on three foundations: firstly, personality measurement scale from psychology, secondly personality scales derived from marketing, lastly unique qualitative research on personality characteristics related with a number of well-known businesses.

Along with 42-item BPS, (Aaker, 1997) recommend that theoretical brand personality framework with five dimension is generic and this can apply throughout product categories. Aaker (1997) stated that BPS might not accurately fit across cultures and more research is required to get the stability of these personality dimensions across culture. Above all, research and literature get increased on brand personality (Azoulay \& Kapferer, 2003) and numerous studies are conducted by researchers on a variety of product categories and across a variety of cultures using a brand personality framework. Aaker (1997) contribution in this domain of brand personality influence the researchers to study (Geuens et al., 2009). Hence, brand personality influences the development of favorable brand evaluations, brand preferences, brand trust, brand affect, and brand loyalty, as well as the development of brand loyalty (Sung \& Kim, 2010)

Murphy et al (2007a) suggested that in background of brand personality, destination personality also enhances the specification of destinations and make them different, unique and outstanding in comparison with its competitors. Hosany et al. (2006) stated that destination personality signifies with the characteristic of human which is being associated with the touristic destination. In correspondence to this fact products hold customers emotional attachments through having reciprocated characteristics of customers (Fournier, 1998) as cited in (Ye et al., 2012). For the first time, researchers Ekinci and Hosany (2006) examined the validity and application of the brand personality framework for tourism destinations, and they found that the model of BPS could be apply to tourism destination as the tourist relates their personality traits to the destinations.

They found that three dimension of brand personality including sincerity, excitement, and conviviality are salient dimensions of the human qualities that are assigned to the destination are referred to as the destination's personality (Chen \& Phou, 2013). Sincerity and excitement were revealed to be the two most important elements of destination personality, while conviviality is a newly discovered destination-specific feature. Since, that 
date till now, the tourism literature getting deep with empirical study of destination personality (Chen \& Phou, 2013).

Furthermore, destinations are comprehended with destination personalities and characteristics in two ways i.e., direct and indirect. In direct way, characteristics allocation means the perception and assumptions of the visitor based on their experience of destination visit. These characteristic falls in symbolic values and personality traits, which consist of tangible factors (e.g., hotel staff, destination attractions and citizen) connected with specific values, memories, events. Likewise, indirect way contains personality features which includes intangible factors of marketing strategies (e.g., promotion, intellectual properties, value-based pricing to customers, celebrities from the country and mass media). Tourist destinations highly positioned \& more distinct, functional attributes must be instigated with additional traits and selling propositions like destination personality to make tourist destinations less substitutable with high spirit of encouraging tourists (Baloglu et al., 2014; Ekinci \& Hosany, 2006; Usakli \& Baloglu, 2011).

In contrast, making destinations highly competitive in tourism market when it comes to marketing and branding of destinations, destination personality is becoming a very useful metaphor (Chen \& Phou, 2013). For example, Western Australia brand which symbolizes 'freshness', 'natural', 'spirited' and 'free' (Crockett \& Wood, 2004). Scotland brand reflects personality traits such as 'straight', 'open', 'honest', 'ethical', 'educated', 'competent', 'warm', 'welcoming', 'friendly', 'accessible', with distinctive voices, names, and attitudes (Hamilton, 2000). Henderson (2000), found that New Asia-Singapore brand is composed of personality characteristics such as 'cosmopolitan', 'youthful', 'vibrant', 'modern', 'reliability', and 'comfort'. Portugal found with personality traits of "traditional", "contemporary", "modern", "sophisticated" in the U.S. travel media. London known as "open-minded", "unorthodox", "vibrant", and "creative" (Hall, 2004), Paris as "romantic" (Morgan \& Pritchard, 2002), and Spain as "friendly" and "family oriented" (Gilmore, 2002).

A large number of research have been carried out to determine the use of brand personality in the tourist industry (Baloglu et al., 2014; Chi et al., 2018; Ekinci \& Hosany, 2006; Gomez Aguilar et al., 2016; Hosany et al., 2006; Hultman et al., 2015; Murphy, Moscardo, et al., 2007; Usakli \& Baloglu, 2011; Xie \& Lee, 2013; Zeugner-Roth \& Žabkar, 2015) and Aaker's BP scale was widely used to measure the destination personality representation e.g., (Ekinci \& Hosany, 2006; Murphy et al., 2007) Originally, Big Five Factor Model and (Aaker, 1997) brand personality scale developed for product/brand attributes measurement not for destination personality, that is why some personality traits that apply on product brand or person resulted irrelevant for destinations (country). Subsequently, the application of five factors, their significance \& stability were not conclusive when applied to cities, countries or destinations in general.

Table 3 contains information on the technique, measurement, and dimensions/attributes that influence the destination's personality. The recent literature review of destination personality reveals that to measure destination personality 42-item BPS of Aaker (1997) were used (see Table 3). According to Chen and Phou (2013); Ekinci and Hosany (2006) ; Ekinci et al (2007) found that three dimension of brand personality attributes with (people) personality traits i.e., sincerity (reliable, sincere, intelligent, successful, and wholesome), excitement (exciting, daring, original, and spirited), and conviviality (friendly, familyoriented, charming) are noticeable dimensions of destination personality based on which human characteristics are attributed to the destination. Additionally, sincerity, excitement and conviviality are the most common used dimensions to measure destination personality 
as shown in table 3 . For the quantitative studies, statistical method and for qualitative studies, interview method were used to determine destination personality (see Table 3).

Table 3: $\quad$ Summary of method, measuring and dimensions of destination personality studies 2006-2018

\begin{tabular}{|c|c|c|c|}
\hline Author (s) & Method & $\begin{array}{l}\text { Destination personality } \\
\text { measure }\end{array}$ & Dimensions \\
\hline $\begin{array}{l}\text { Ekinci and } \\
\text { Hosany (2006) }\end{array}$ & $\begin{array}{l}\text { Descriptive statistics, } \\
\text { Exploratory factor } \\
\text { analysis; Confirmatory } \\
\text { factor analysis; }\end{array}$ & $\begin{array}{l}\text { Structured: Aaker (1997) } \\
\text { BPS, content validity, } 27 \\
\text { items of BPS. } \\
\text { 5-point Likert-type scale }\end{array}$ & $\begin{array}{l}\text { 3 Dimensions: } \\
\text { 1. Sincerity } \\
\text { 2. Excitement } \\
\text { 3. Conviviality }\end{array}$ \\
\hline $\begin{array}{l}\text { Hosany et al. } \\
\text { (2006) }\end{array}$ & $\begin{array}{lr}\text { Exploratory } & \text { factor } \\
\text { analysis; } & \text { OLS } \\
\text { regression; } & \text { Canonical } \\
\text { correlation analysis }\end{array}$ & $\begin{array}{l}\text { Structured: Aaker (1997) } \\
\text { BPS, content validity, } 27 \\
\text { items of BPS. } \\
\text { 5-point Likert-type scale }\end{array}$ & $\begin{array}{l}\text { 3 Dimensions: } \\
\text { 1. Sincerity } \\
\text { 2. Excitement } \\
\text { 3. Conviviality }\end{array}$ \\
\hline $\begin{array}{l}\text { Murphy et al. } \\
\text { (2007b) }\end{array}$ & $\begin{array}{lr}\text { Descriptive } & \text { statistics; } \\
\text { Exploratory factor } \\
\text { analysis; Paired t-test } \\
\text { and independent t-test }\end{array}$ & $\begin{array}{l}\text { Structured: } 20 \text { items of } \\
\text { Aaker (1997) BPS, } \\
\text { Unstructured: Open- } \\
\text { ended questions } \\
\text { 5-point Likert-type scale }\end{array}$ & $\begin{array}{l}\text { Cairns } \\
\text { dimensions): } \\
\text { 1. Sincere, } \\
\text { 2. Sophisticated, } \\
\text { 3. Outdoorsy. }\end{array}$ \\
\hline & & & $\begin{array}{l}\text { Whitsunday } \\
\text { Islands } \\
\text { dimensions): } \\
\text { 1.Upper class } \\
\text { 2. Honest } \\
\text { 3. Exciting } \\
\text { 4. Tough. }\end{array}$ \\
\hline $\begin{array}{l}\text { d'Astous and } \\
\text { Boujbel (2007) }\end{array}$ & Individual interviews & $\begin{array}{l}\text { Structured: previous } \\
\text { personality scales, } \\
\text { Unstructured: interviews }\end{array}$ & $\begin{array}{l}6 \text { Dimensions: } \\
\text { 1. Agreeableness } \\
\text { 2. Wickedness }\end{array}$ \\
\hline & & 5-point bipolar scales & $\begin{array}{l}\text { 3. Snobbism } \\
\text { 4. Assiduousness } \\
\text { 5. Conformity } \\
\text { 6. Unobtrusiveness }\end{array}$ \\
\hline Prayag (2007) & $\begin{array}{l}\text { Unstructured: } \\
\text { Projective techniques, } \\
\text { in-depth interviews }\end{array}$ & No dimensions & No dimensions \\
\hline Pitt et al. (2007) & $\begin{array}{l}\text { Content analysis and } \\
\text { correspondence } \\
\text { analysis. }\end{array}$ & $\begin{array}{lr}\text { A list of } 922 \text { synonyms to } \\
\text { Aaker (1997) } 42 \\
\text { personality traits were } \\
\text { collected, and then, }\end{array}$ & $\begin{array}{l}\text { Each country was } \\
\text { evaluated based } \\
\text { on Aaker (1997) } \\
\text { BP dimensions. }\end{array}$ \\
\hline
\end{tabular}




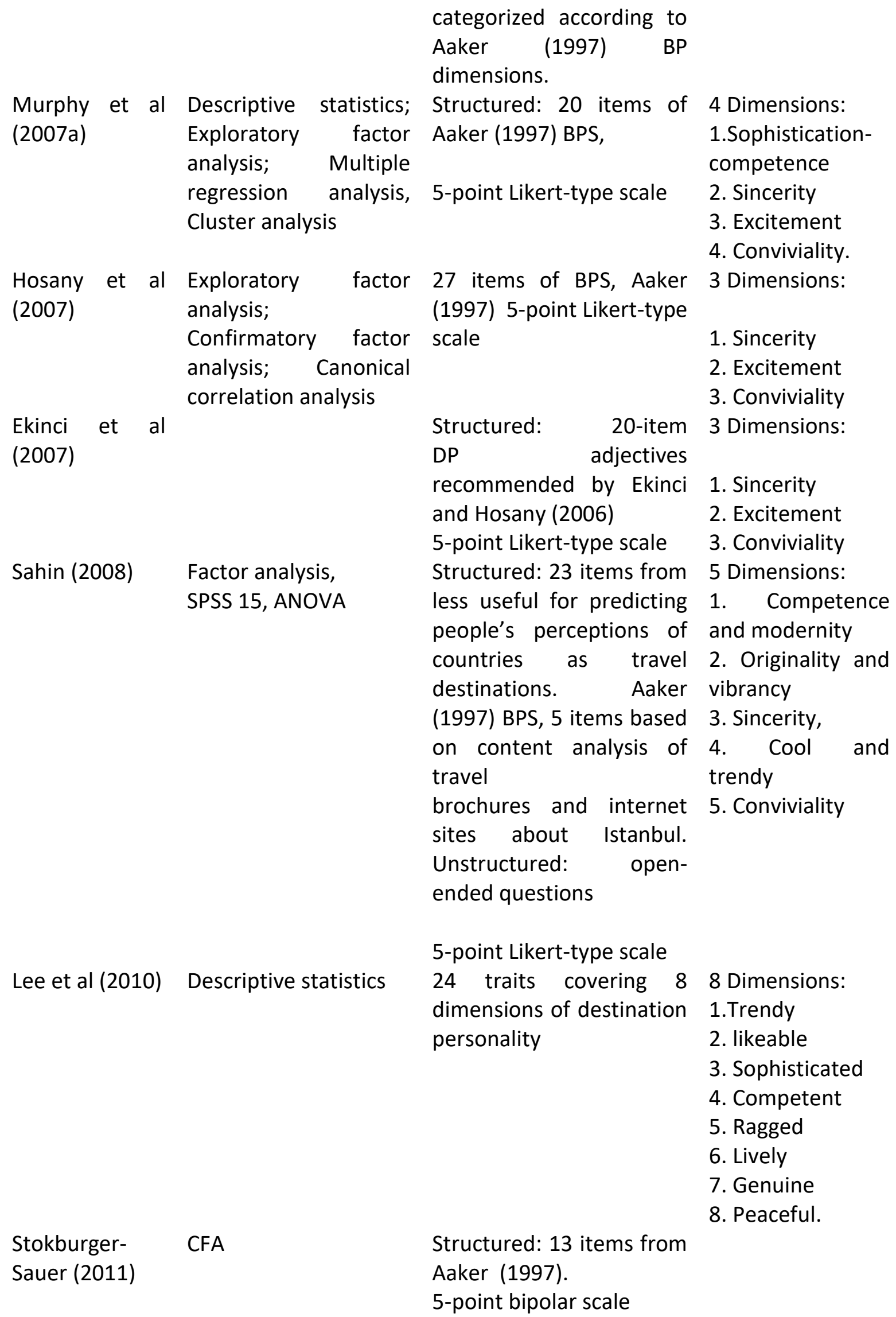




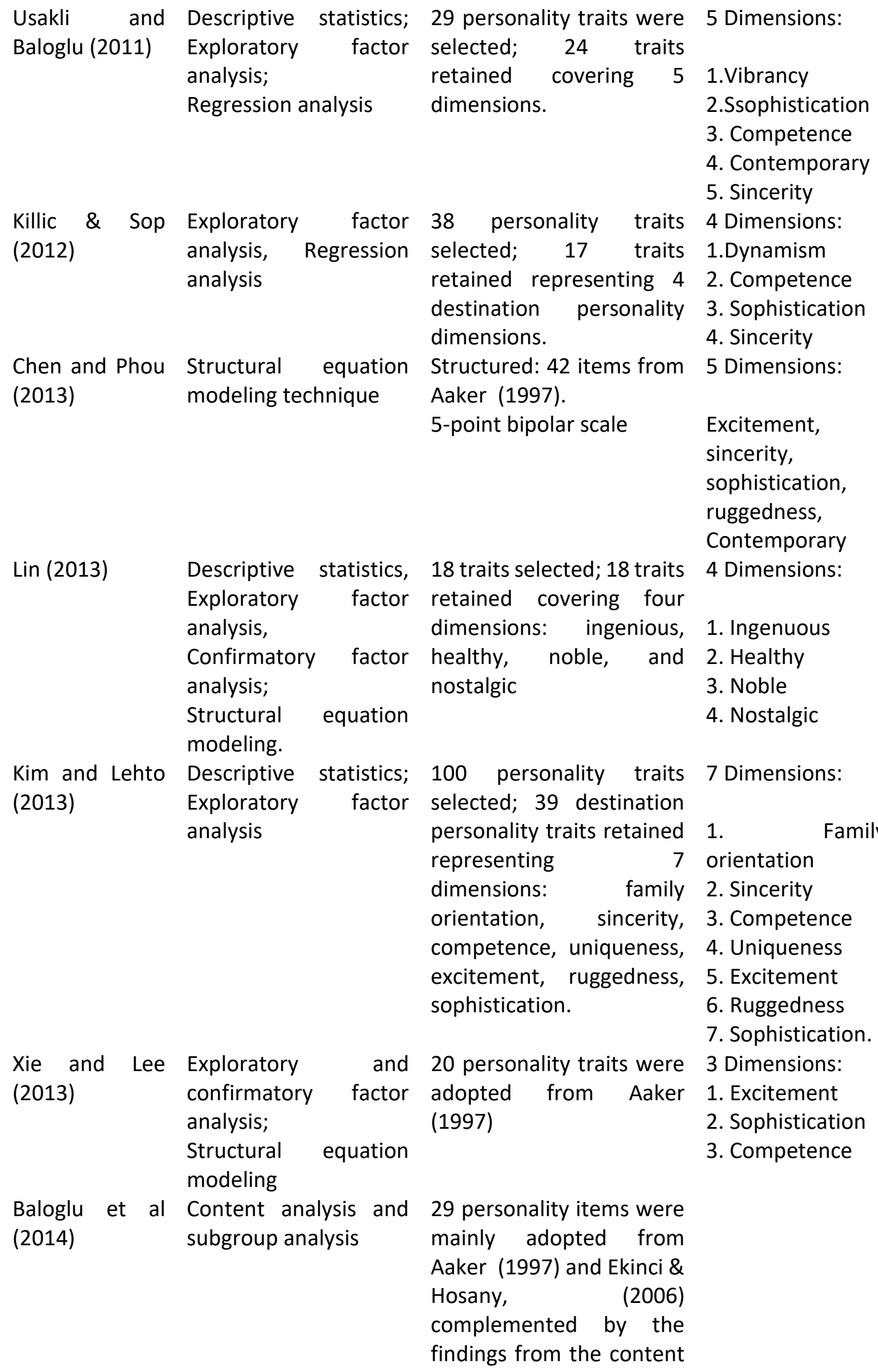

Baloglu et al Content analysis and 29 personality items were (2014) subgroup analysis mainly adopted from Aaker (1997) and Ekinci \& Hosany, (2006) complemented by the findings from the content 


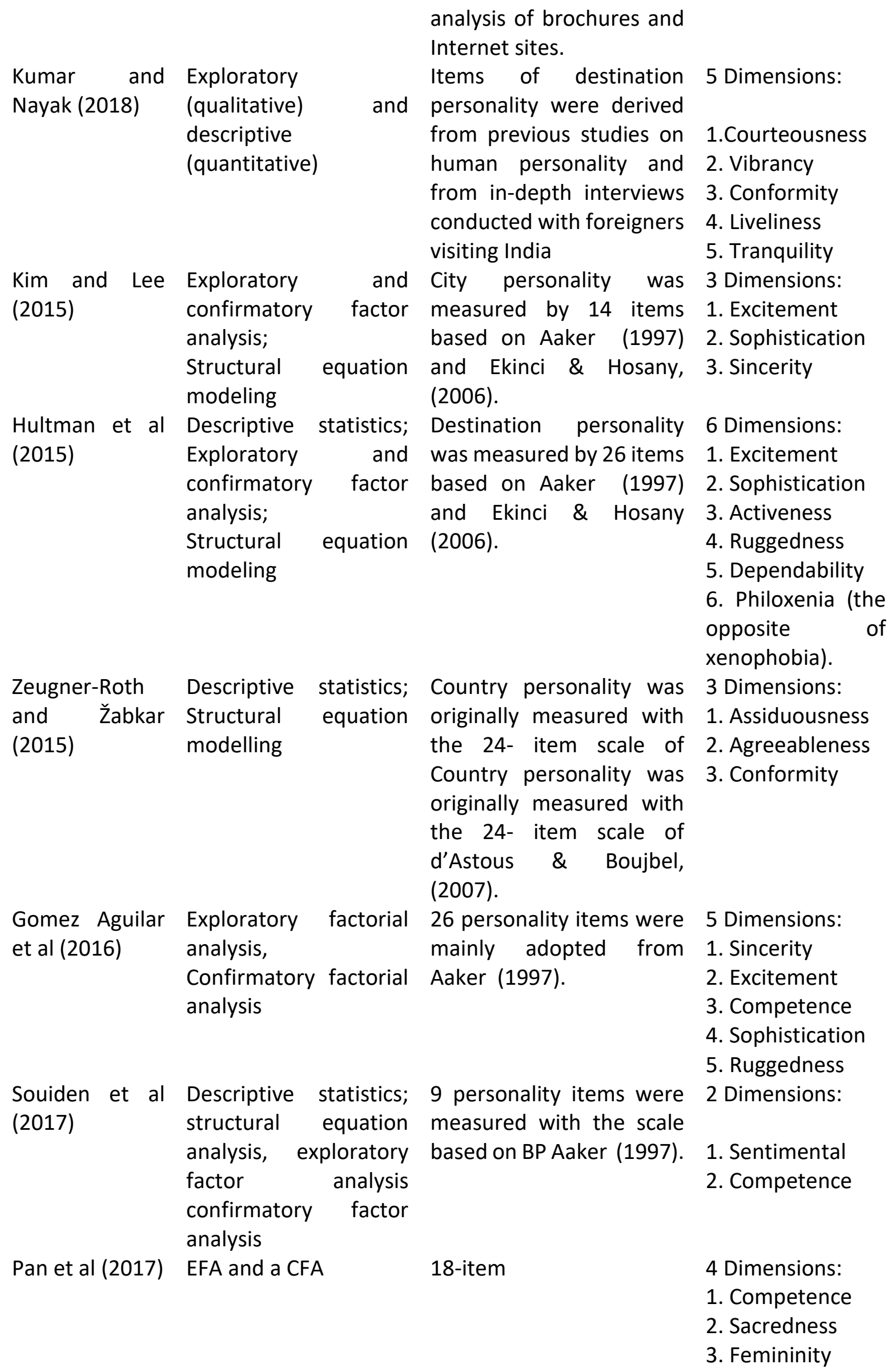




\begin{tabular}{|c|c|c|c|}
\hline Kim et al (2018) & $\begin{array}{l}\text { Descriptive statistics } \\
\text { Exploratory factor } \\
\text { analysis, confirmatory } \\
\text { factor analysis, SPSS } \\
\text { and SPSS Amos } 21.0\end{array}$ & $\begin{array}{l}\text { Structured } 15 \text { items were } \\
\text { measured with the scale } \\
\text { based on BP Aaker (1997). }\end{array}$ & $\begin{array}{l}\text { 4. Excitement } \\
\text { 4 Dimensions: } \\
\text { 1. Excitement } \\
\text { 2. Sincerity } \\
\text { 3. Comfort } \\
\text { 4. Activeness }\end{array}$ \\
\hline Chi et al (2018) & $\begin{array}{l}\text { The maximum } \\
\text { likelihood (ML) } \\
\text { method of estimation } \\
\text { in combination with } \\
\text { the two-stage process } \\
\text { was utilized to analyse } \\
\text { the data }\end{array}$ & $\begin{array}{l}\text { Structured } 9 \text { items were } \\
\text { measured with the scale } \\
\text { based on Aaker (1997). }\end{array}$ & $\begin{array}{l}\text { 3 Dimensions: } \\
\text { 1. Conviviality } \\
\text { 2. Sophistication } \\
\text { 3. Vibrancy }\end{array}$ \\
\hline
\end{tabular}

The results of the survey methodologies used to determine destination personality revealed that developed countries were the most often examined destination type, followed by cities, and that the majority of data and information was gathered from visitors to particular destinations (see Table 4).

Table 4: $\quad$ Summary of survey methods of destination personality studies 2006-2018

\begin{tabular}{|c|c|c|c|}
\hline Author (s) & Destination Type & $\begin{array}{l}\text { Sample } \\
\text { Size }\end{array}$ & $\begin{array}{l}\text { Sample } \\
\text { Type }\end{array}$ \\
\hline $\begin{array}{l}\text { Ekinci and Hosany } \\
\text { (2006) }\end{array}$ & $\begin{array}{l}\text { A number of destinations by recalling the last } \\
\text { destination visited }\end{array}$ & 250 & Visitors \\
\hline $\begin{array}{l}\text { Hosany et al } \\
(2006)\end{array}$ & Three different cities in the United Kingdom. & 148 & Visitors \\
\hline $\begin{array}{l}\text { Murphy et al } \\
\text { (2007b) }\end{array}$ & $\begin{array}{l}\text { Two destinations in Queensland, Australia: } \\
\text { Cairns and Whitsunday Islands }\end{array}$ & 464 & Visitors \\
\hline $\begin{array}{l}\text { d'Astous and } \\
\text { Boujbel (2007) }\end{array}$ & $\begin{array}{l}\text { A number of countries representing } \\
\text { five continents }\end{array}$ & $\begin{array}{l}\text { French } \\
\text { speaking } \\
\text { Canadians }\end{array}$ & ------- \\
\hline Prayag (2007) & South Africa - Cape Town & 85 & Visitors \\
\hline Pitt et al (2007) & 10 African countries & $\begin{array}{l}\text { Official } \\
\text { tourism } \\
\text { websites } \\
\text { of } \quad 10 \\
\text { African } \\
\text { countries }\end{array}$ & ------- \\
\hline $\begin{array}{l}\text { Murphy et al } \\
(2007 a)\end{array}$ & Queensland, Australia & 277 & Visitors \\
\hline $\begin{array}{l}\text { Hosany et al } \\
(2007)\end{array}$ & $\begin{array}{l}\text { A number of destinations by recalling the last } \\
\text { destination visited }\end{array}$ & 148 & Visitors \\
\hline Ekinci et al (2007) & Mediterranean region of Turkey & 365 & Visitors \\
\hline Sahin (2008) & Istanbul, Turkey & 272 & Visitors \\
\hline
\end{tabular}




\begin{tabular}{|c|c|c|c|}
\hline Lee et al (2010) & France, USA, China & 429 & Visitors \\
\hline $\begin{array}{l}\text { Stokburger-Sauer } \\
\text { (2011) }\end{array}$ & Ireland & 421 & Visitors \\
\hline $\begin{array}{l}\text { Usakli and Baloglu } \\
\text { (2011) }\end{array}$ & Las Vegas. & 368 & Visitors \\
\hline Killic \& Sop (2012) & Turkey & 226 & Visitors \\
\hline $\begin{array}{l}\text { Chen and Phou } \\
\text { (2013) }\end{array}$ & Cambodia & 428 & Visitors \\
\hline $\operatorname{Lin}(2013)$ & Taiwan. & 315 & Visitors \\
\hline $\begin{array}{l}\text { Kim and Lehto } \\
\text { (2013) }\end{array}$ & South Korea & 480 & Visitors \\
\hline $\begin{array}{l}\text { Xie and Lee } \\
(2013)\end{array}$ & Beijing & 497 & Visitors \\
\hline $\begin{array}{l}\text { Baloglu et al } \\
(2014)\end{array}$ & Jamaica's & 312 & Visitors \\
\hline $\begin{array}{l}\text { Kumar and Nayak } \\
\text { (2018) }\end{array}$ & India. & 152 & Visitors \\
\hline $\begin{array}{l}\text { Kim and Lee } \\
(2015)\end{array}$ & South Korea. & 302 & Visitors \\
\hline $\begin{array}{l}\text { Hultman et al } \\
\text { (2015) }\end{array}$ & Taiwan & 490 & Visitors \\
\hline $\begin{array}{l}\text { Zeugner-Roth and } \\
\text { Žabkar (2015) }\end{array}$ & Austria, Italy, Germany & 411 & Visitors \\
\hline $\begin{array}{l}\text { Gomez Aguilar et } \\
\text { al. (2016) }\end{array}$ & Spain destinations: Granada, Torremolinos. & 329 & Visitors \\
\hline $\begin{array}{l}\text { Souiden et al } \\
\text { (2017) }\end{array}$ & Dubai & 173 & Visitors \\
\hline Pan et al (2017) & Chine & 515 & Visitors \\
\hline Kim et al (2018) & South Korea & 316 & Visitors \\
\hline Chi et al (2018) & Italy: Sardinia & 1266 & Visitors \\
\hline
\end{tabular}

Apart from all this still more study \& research is required to understand the destination personality role and its importance for destination branding. In spite of the growing body of work on destination branding in general, particularly at a national or country level, little research has been done to determine whether or not tourists attribute tourism destinations with brand personality characteristics and, if so, whether or not this influences their travel behaviour.

\section{Conclusion}

Destination personality consider as brand personality in context of tourism literature. This study accomplished a comprehensive evaluation of the literature of destination personality from 2006-2018, synthesizing literature with regards to the concepts, dimensions, and measurements. The review of the more recent destination personality literature reveals that 42-item BPS of (Aaker, 1997)were used to measure destination personality. However, the most noticeable dimensions of destination personality based on which human characteristics are attributed to the destination are sincerity, excitement and conviviality and researchers used these dimensions are most commonly to measure destination personality. These 
noticeable dimensions of destination personality sincerity and excitement were found to be two main dimensions and conviviality is newly specific to destination.

\section{References}

Aaker, J. L. (1997). Dimensions of brand personality. Journal of Marketing Research, 34(3), 347-356.

Aslan, S. (2008). Kişilik, huy ve psikopatoloji. Rewiews, Cases and Hypotheses in Psychiatry RCHP, 2(1-2), 7-18.

Azoulay, A., \& Kapferer, J.-N. (2003). Do brand personality scales really measure brand personality? Journal of Brand Management, 11(2), 143-155.

Baloglu, S., Henthorne, T. L., \& Sahin, S. (2014). Destination image and brand personality of Jamaica: A model of tourist behavior. Journal of Travel \& Tourism Marketing, 31(8), 1057-1070.

Barrick, M. R., \& Mount, M. K. (1991). The big five personality dimensions and job performance: a meta-analysis. Personnel Psychology, 44(1), 1-26.

Bellou, V., Stylos, N., \& Rahimi, R. (2018). Predicting hotel attractiveness via personality traits of applicants: the moderating role of self-esteem and work experience. International Journal of Contemporary Hospitality Management.

Berno, T., \& Ward, C. (2005). Innocence abroad: A pocket guide to psychological research on tourism. American Psychologist, 60(6), 593.

Burruss, J. D., \& Kaenzig, L. (1999). Introversion: The often forgotten factor impacting the gifted. Virginia Association for the Gifted Newsletter, 21(1), 1-4.

Busato, V. V, Prins, F. J., Elshout, J. J., \& Hamaker, C. (2000). Intellectual ability, learning style, personality, achievement motivation and academic success of psychology students in higher education. Personality and Individual Differences, 29(6), 1057-1068.

Cattell, R. B., \& Eber, H. W. (1964). Sixteen personality factor questionnaire. Institute for Personality and Ability Testing.

Chen, C. F., \& Phou, S. (2013). A closer look at destination: Image, personality, relationship and loyalty. Tourism Management. https://doi.org/10.1016/j.tourman.2012.11.015

Chi, C. G.-Q., Pan, L., \& Del Chiappa, G. (2018). Examining destination personality: Its antecedents and outcomes. Journal of Destination Marketing \& Management, 9, 149159.

Clark, L. A., \& Watson, D. (1991). General affective dispositions in physical and psychological health. Handbook of Social and Clinical Psychology, 12, 221-245.

Costa Jr, P. T., \& McCrae, R. R. (1992). The five-factor model of personality and its relevance to personality disorders. Journal of Personality Disorders, 6(4), 343-359.

Costa Jr, P. T., McCrae, R. R., \& Dye, D. A. (1991). Facet scales for agreeableness and conscientiousness: A revision of the NEO Personality Inventory. Personality and Individual Differences, 12(9), 887-898.

Crockett, S. R., \& Wood, L. J. (2004). Western Australia: building a state brand. Destination Branding: Creating the Unique Destination Proposition, 185-206.

d'Astous, A., \& Boujbel, L. (2007). Positioning countries on personality dimensions: Scale development and implications for country marketing. Journal of Business Research, 60(3), 231-239.

Dannar, P. (2016). If you want creativity in your organizations, seek out the introvert. Journal of Leadership Studies, 10(1), 40-41.

Denissen, J. J. A., \& Penke, L. (2008). Motivational individual reaction norms underlying the 
Five-Factor model of personality: First steps towards a theory-based conceptual framework. Journal of Research in Personality, 42(5), 1285-1302.

Dollinger, S. J., \& Orf, L. A. (1991). Personality and performance in "personality": Conscientiousness and openness. Journal of Research in Personality, 25(3), 276-284.

Ekinci, Y., \& Hosany, S. (2006). Destination personality: An application of brand personality to tourism destinations. Journal of Travel Research, 45(2), 127-139.

Ekinci, Y., Sirakaya-Turk, E., \& Baloglu, S. (2007). Host image and destination personality. Tourism Analysis, 12(5-6), 433-446.

Eysenck, Hans J. (1981). General features of the model. In A model for personality (pp. 1-37). Springer.

Eysenck, Hans Jürgen. (1992). A hundred years of personality research, from Heymans to modern times: Lecture. Bohn Stafleu Van Loghum.

Eysenck, M. W. (1985). Anxiety and cognitive-task performance. Personality and Individual Differences, 6(5), 579-586.

Fournier, S. (1998). Consumers and their brands: Developing relationship theory in consumer research. Journal of Consumer Research, 24(4), 343-373.

Freyd, M. (1924). Introverts and Extroverts. Psychological Review, 31(1), 74.

Geuens, M., Weijters, B., \& De Wulf, K. (2009). A new measure of brand personality. International Journal of Research in Marketing, 26(2), 97-107.

Gilmore, F. (2002). Branding for success. Destination Branding: Creating the Unique Destination Proposition, 57-65.

Gnoth, J., Baloglu, S., Ekinci, Y., \& Sirakaya-Turk, E. (2007). Building destination brands. Tourism Analysis, 12(5/6), 339-483.

Goldberg, L. R. (1990). An alternative" description of personality": the big-five factor structure. Journal of Personality and Social Psychology, 59(6), 1216.

Gomez Aguilar, A., Yaguee Guillen, M. J., \& Villasenor Roman, N. (2016). Destination brand personality: An application to Spanish tourism. International Journal of Tourism Research, 18(3), 210-219.

Graziano, W. G., \& Eisenberg, N. (1997). Agreeableness: A dimension of personality. In Handbook of personality psychology (pp. 795-824). Elsevier.

Gretzel, U., Mitsche, N., Hwang, Y.-H., \& Fesenmaier, D. R. (2006). Travel personality testing for destination recommendation systems. Destin Recomm Syst Behav Found Appl. CABI, Oxfordshire, 121-136.

Hall, J. (2004). Branding Britain. Journal of Vacation Marketing, 10(2), 171-185.

Hamilton, K. (2000). Project Galore: Qualitative Research and Leveraging Scotland's Brand Equity. Journal of Advertising Research, 40(1), 107-111.

Hassan, G. (2001). An empirical assessment of the configural invariance of the brand personality scale: a comparison involving ethnic groups and brands in Canada. Concordia University.

Henderson, J. C. (2000). Selling places: the new Asia-Singapore brand. Journal of Tourism Studies, 11(1), 36-44.

Hills, P., \& Argyle, M. (2001). Happiness, introversion-extraversion and happy introverts. Personality and Individual Differences, 30(4), 595-608.

Hogan, R. E. (1983). A socioanalytic theory of personality. Nebraska Symposium on Motivation. Nebraska Symposium on Motivation, 55-89.

Hosany, S., Ekinci, Y., \& Uysal, M. (2006). Destination image and destination personality: An application of branding theories to tourism places. Journal of Business Research, 59(5), 
$638-642$.

Hosany, S., Ekinci, Y., \& Uysal, M. (2007). Destination image and destination personality. International Journal of Culture, Tourism and Hospitality Research.

Huang, L., Gursoy, D., \& Xu, H. (2014). Impact of personality traits and involvement on prior knowledge. Annals of Tourism Research, 48, 42-57.

Hultman, M., Skarmeas, D., Oghazi, P., \& Beheshti, H. M. (2015). Achieving tourist loyalty through destination personality, satisfaction, and identification. Journal of Business Research. https://doi.org/10.1016/j.jbusres.2015.06.002

Jalili, S., \& Mall-Amiri, B. (2015). The difference between extrovert and introvert EFL teachers' classroom management. Theory and Practice in Language Studies, 5(4), 826.

Jani, D., \& Han, H. (2013). Personality, social comparison, consumption emotions, satisfaction, and behavioral intentions: How do these and other factors relate in a hotel setting? International Journal of Contemporary Hospitality Management.

Jani, D., \& Han, H. (2014). Testing the moderation effect of hotel ambience on the relationships among social comparison, affect, satisfaction, and behavioral intentions. Journal of Travel \& Tourism Marketing, 31(6), 731-746.

Jung, C. G. (1923). Psychological Types, trans. H. Godwin Baynes. New York: Pantheon Books.

Kavenská, V., \& Simonová, H. (2015). Ayahuasca tourism: participants in shamanic rituals and their personality styles, motivation, benefits and risks. Journal of Psychoactive Drugs, 47(5), 351-359.

Keller, K. L. (1993). Conceptualizing, measuring, and managing customer-based brand equity. Journal of Marketing, 57(1), 1-22.

KILICcedil, B., \& Sop, S. A. (2012). Destination personality, self-congruity and loyalty. Journal of Hospitality Management and Tourism, 3(5), 95-105.

Kim, H.-B., \& Lee, S. (2015). Impacts of city personality and image on revisit intention. International Journal of Tourism Cities.

Kim, M. J., Bonn, M., Lee, C.-K., \& Hahn, S. S. (2018). Effects of personality traits on visitors attending an exposition: The moderating role of anxiety attachment. Asia Pacific Journal of Tourism Research, 23(5), 502-519.

Kim, S., \& Lehto, X. Y. (2013). Projected and perceived destination brand personalities: The case of South Korea. Journal of Travel Research, 52(1), 117-130.

Kim, W., Malek, K., Kim, N., \& Kim, S. (2018). Destination personality, destination image, and intent to recommend: The role of gender, age, cultural background, and prior experiences. Sustainability, 10(1), 87.

Kim, Y. G., Suh, B. W., \& Eves, A. (2010). The relationships between food-related personality traits, satisfaction, and loyalty among visitors attending food events and festivals. International Journal of Hospitality Management, 29(2), 216-226.

Kumar, V., \& Nayak, J. K. (2018). Destination personality: Scale development and validation. Journal of Hospitality \& Tourism Research, 42(1), 3-25.

Kuo, N.-T., Cheng, Y.-S., Chiu, W.-H., \& Cho, S. (2016). Personalities of travel agents with strong sales records in Taiwan. Asia Pacific Journal of Tourism Research, 21(9), 1001-1019.

Kvasova, O. (2015). The Big Five personality traits as antecedents of eco-friendly tourist behavior. Personality and Individual Differences, 83, 111-116.

Landers, R. N., \& Lounsbury, J. W. (2006). An investigation of Big Five and narrow personality traits in relation to Internet usage. Computers in Human Behavior, 22(2), 283-293.

Larsen, H. G. (2018). The'mental topography' of the Shanghai city brand: A netnographic approach to formulating city brand positioning strategies. Journal of Destination 
Marketing \& Management, 8, 90-101.

Larsen, R. J., \& Ketelaar, T. (1991). Personality and susceptibility to positive and negative emotional states. Journal of Personality and Social Psychology, 61(1), 132.

Lee, J., Soutar, G., \& Quintal, V. (2010). Destination personality: Cross-country comparisons. Proceedings of Australian and New Zealand Marketing Academy Conference, 2010.

Lee, T. H., \& Tseng, C. H. (2015). How personality and risk-taking attitude affect the behavior of adventure recreationists. Tourism Geographies, 17(3), 307-331.

Leri, I., \& Theodoridis, P. (2020). How do personality traits affect visitor's experience, emotional stimulation and behaviour? The case of wine tourism. Tourism Review.

Leung, R., \& Law, R. (2010). A review of personality research in the tourism and hospitality context. Journal of Travel \& Tourism Marketing, 27(5), 439-459.

Li, X., \& Kaplanidou, K. (2013). The impact of the 2008 Beijing Olympic Games on China's destination brand: A US-based examination. Journal of Hospitality \& Tourism Research, 37(2), 237-261.

Lin, C.-H. (2013). Determinants of revisit intention to a hot springs destination: Evidence from Taiwan. Asia Pacific Journal of Tourism Research, 18(3), 183-204.

Lin, Y., Kerstetter, D., Nawijn, J., \& Mitas, O. (2014). Changes in emotions and their interactions with personality in a vacation context. Tourism Management, 40, 416-424.

Lucas, R. E., \& Diener, E. (2001). Understanding extraverts' enjoyment of social situations: The importance of pleasantness. Journal of Personality and Social Psychology, 81(2), 343.

McCrae, R. R. (1993). Openness to experience as a basic dimension of personality. Imagination, Cognition and Personality, 13(1), 39-55.

McCrae, R. R., \& Costa, P. T. (1987). Validation of the five-factor model of personality across instruments and observers. Journal of Personality and Social Psychology, 52(1), 81.

McKercher, B., Law, R., \& Lam, T. (2006). Rating tourism and hospitality journals. Tourism Management, 27(6), 1235-1252.

Mischel, W., \& Shoda, Y. (1995). A cognitive-affective system theory of personality: reconceptualizing situations, dispositions, dynamics, and invariance in personality structure. Psychological Review, 102(2), 246.

Moghavvemi, S., Woosnam, K. M., Paramanathan, T., Musa, G., \& Hamzah, A. (2017). The effect of residents' personality, emotional solidarity, and community commitment on support for tourism development. Tourism Management, 63, 242-254.

Morgan, N., \& Pritchard, A. (2002). Contextualizing destination branding. Destination Branding: Creating the Unique Destination Proposition, 11-41.

Morrone-Strupinsky, J. V, \& Lane, R. D. (2007). Parsing positive emotion in relation to agentic and affiliative components of extraversion. Personality and Individual Differences, 42(7), 1267-1278.

Muharrami, M. L., Setiyadi, A. B., \& Hasan, H. (2013). A comparative study between introvert and extrovert students personality in listening achievement. U-JET, 2(8).

Murphy, L., Benckendorff, P., \& Moscardo, G. (2007). Destination brand personality: Visitor perceptions of a regional tourism destination. Tourism Analysis, 12(5-6), 419-432.

Murphy, L., Moscardo, G., \& Benckendorff, P. (2007). Using brand personality to differentiate regional tourism destinations. Journal of Travel Research, 46(1), 5-14.

Niranga, W. A. M., \& Dharmadasa, M. P. P. (2018). Introverted and Extroverted Personality Traits of Leaders and OCB of Followers: A Moderating Effect of Leader-Member Relationship of IT Industry in Sri Lanka.

Pan, L., Zhang, M., Gursoy, D., \& Lu, L. (2017). Development and validation of a destination 
personality scale for mainland Chinese travelers. Tourism Management, 59, 338-348.

Phau, I., \& Lau, K. C. (2000). Conceptualising brand personality: A review and research propositions. Journal of Targeting, Measurement and Analysis for Marketing, 9(1), 5269.

Pitt, L. F., Opoku, R., Hultman, M., Abratt, R., \& Spyropoulou, S. (2007). What I say about myself: Communication of brand personality by African countries. Tourism Management, 28(3), 835-844.

Prayag, G. (2007). Exploring the relationship between destination image and brand personality of a tourist destination: An application of projective techniques. Journal of Travel and Tourism Research, 2(Fall 2007), 111-130.

Rothmann, S., \& Coetzer, E. P. (2003). The big five personality dimensions and job performance. SA Journal of Industrial Psychology, 29(1), 68-74.

Sahin, S. (2008). Brand personality and destination image of Istanbul: A comparison across nationalities.

Servidio, R. (2015). Images, affective evaluation and personality traits in tourist behaviour: An exploratory study with Italian postcards. Tourism Management Perspectives, 16, 237246.

Souiden, N., Ladhari, R., \& Chiadmi, N. E. (2017). Destination personality and destination image. Journal of Hospitality and Tourism Management, 32, 54-70.

Stajkovic, A. D., Bandura, A., Locke, E. A., Lee, D., \& Sergent, K. (2018). Test of three conceptual models of influence of the big five personality traits and self-efficacy on academic performance: A meta-analytic path-analysis. Personality and Individual Differences, 120, 238-245.

Stemmler, G., \& Wacker, J. (2010). Personality, emotion, and individual differences in physiological responses. Biological Psychology, 84(3), 541-551.

Stokburger-Sauer, N. E. (2011). The relevance of visitors' nation brand embeddedness and personality congruence for nation brand identification, visit intentions and advocacy. Tourism Management, 32(6), 1282-1289.

Sung, Y., \& Kim, J. (2010). Effects of brand personality on brand trust and brand affect. Psychology \& Marketing, 27(7), 639-661.

Tang, C. M. F., \& Lam, D. (2017). The role of extraversion and agreeableness traits on Gen Y's attitudes and willingness to pay for green hotels. International Journal of Contemporary Hospitality Management.

Tasci, A. D. A., \& Kozak, M. (2006). Destination brands vs destination images: Do we know what we mean? Journal of Vacation Marketing, 12(4), 299-317.

Tsiakali, K. (2018). User-generated-content versus marketing-generated-content: Personality and content influence on traveler's behavior. Journal of Hospitality Marketing \& Management, 27(8), 946-972.

Usakli, A., \& Baloglu, S. (2011). Brand personality of tourist destinations: An application of self-congruity theory. Tourism Management, 32(1), 114-127.

Vespestad, M. K., \& Mehmetoglu, M. (2017). The interrelationship between personality traits and psychological constraints on adventure activity participation. In Advances in Hospitality and Leisure. Emerald Publishing Limited.

Ward, S. (1974). Consumer socialization. Journal of Consumer Research, 1(2), 1-14.

Washington, R. R., Sutton, C. D., \& Feild, H. S. (2006). Individual differences in servant leadership: The roles of values and personality. Leadership \& Organization Development Journal. 
Xie, K. L., \& Lee, J.-S. (2013). Toward the perspective of cognitive destination image and destination personality: The case of Beijing. Journal of Travel \& Tourism Marketing, 30(6), 538-556.

Ye, Q., Song, H., \& Li, T. (2012). Cross-institutional collaboration networks in tourism and hospitality research. Tourism Management Perspectives, 2, 55-64.

Ying, T., \& Norman, W. C. (2017). Personality effects on the social network structure of boundary-spanning personnel in the tourism industry. Journal of Hospitality \& Tourism Research, 41(5), 515-538.

Yoo, K.-H., \& Gretzel, U. (2011). Influence of personality on travel-related consumergenerated media creation. Computers in Human Behavior, 27(2), 609-621.

Zeugner-Roth, K. P., \& Žabkar, V. (2015). Bridging the gap between country and destination image: Assessing common facets and their predictive validity. Journal of Business Research, 68(9), 1844-1853. 